\title{
One Step Forward, One Step Back: Shale Gas in Denmark and Sweden
}

\author{
Vanessa Becker / Anne Werner \\ Technical University of Applied Sciences, Wildau, Germany
}

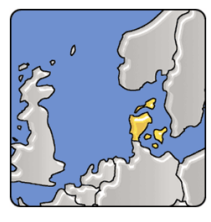

Abstract. Denmark and Sweden take two-fold positions on the question whether shale gas should be developed. At first sight, it appears the governments are supportive by licencing exploration to domestic and foreign companies. However, Denmark has suspended issuance of new licenses as doubts of extraction activities have risen. Sweden was forced to give landowners and municipalities a say in decision-making, and there is a larger context of mining minerals policy controversy. Even though both countries only have exploration

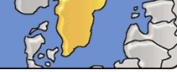
activities at the moment, and the economic promise is yet unclear, public awalties for governments and industry to proceed without open discussions and debates. Scandinavia's green image is at stake as the new fossil fuel opportunities are in conflict with the ambitious goals for renewable energy development. Both countries now have to prioritise energy self-sufficiency and industrial economics versus ecological consciousness.

Keywords: Denmark, energy, energy policy, fracking, hydraulic fracturing, mining, protest, public acceptance, regulatory politics, Scandinavia, shale gas, Sweden, unconventional gas

Author: Vanessa Becker and Anne Werner are M.A. candidates in the European Management program at Technical University of Applied Sciences, Wildau, Germany.

\section{Introduction}

Acceptance of shale gas development may be increasing in Europe. Rising energy costs, better public understanding of the issue and fear of losing economic competitiveness contribute to a positive view. However, many people are still reflexively opposed, deeply concerned with environmental and other risks, e.g. seismic activity (vulgo earthquakes). The debate about the development of unconventional gas is continuing and is increasingly characterised by informed participants, leading to more informed decision-making (Seaton, 2013).

There is no political consensus at EU level (Eberhardt et al., 2013). For the time being, member states govern through author- isations and permits as well as general legislation in the field of prospection, exploration and production of hydrocarbons (Philippe \& Partners, 2011).

In Scandinavia, Alum Shale resources exist as one type of shale case occurrences. Sweden, it is estimated, contributes to these Scandinavian resources with 0.3 trillion cubic meters $(\mathrm{tcm})$ of technically recoverable shale gas. Denmark has $4.5 \mathrm{tcm}$ shale gas in place. However, only $0.9 \mathrm{tcm}$ of Danish resources are technically recoverable. Consequently, for the purpose of this article, only Denmark and Sweden will be analysed as they have the greatest potential among the Scandinavian Countries to go forward in producing shale in the near future. The map of figure 1 shows current assessment of the region which comprises the Scandinavian potentials for shale gas. As it is shown in the illustration, most of Denmark and large parts of Southern Sweden are considered to have shale gas occurrences. Most of the area has been classified as Alum Shale with characteristics of being shallow, thin and immature (ARI, 2013).

In concerns to Sweden, licence-holders include Gripen Gas $\mathrm{AB}$, Energigas and Tekniska Verken Linköping AB. All are active in south-central Sweden. Shell AB has been most active in Southern Sweden between 2008 and 2011 (ARI, 2013). These firms' activities have provoked significant public worries and anti-fracking activism. This poses moderate operational and security risks to shale gas development (Control Risks' Offices, 2012).

Immense objection to Shell plans caused major public pressure to give municipalities the right to veto drilling. The Swedish government decided to review and evaluate the Minerals' Act which regulates the prospection, exploration and production of hydrocarbons, including shale gas (Philippe \& Partners, 2011).

In the case of Denmark, however, has stopped issuing new licenses. Before, in 2010, the government granted two licenses to Total E\&P Denmark B.V., a subsidiary of the French Total company, to conduct research surveys, followed by test drillings in the areas of Northern Zealand and Northern Jutland which are supposed to last for six years (ARI, 2013; Eberhardt et al., 2013).

Depending on the results, Denmark will decide on further policy at a later point of time. Anti-fracking activism is moderate in Denmark; protest is rather unorganised and receives little media attention (Madsen, Have, Woodrow, Olsen, 2012). But the Danish public certainly cares about environmental and energy issues. This leads to political and security risks to unconventional gas development (Control Risks' Offices, 2012). 
Scandinavia has generally shown reluctance to engage with the question whether unconventional gas should be developed. As it is well known, the Scandinavian countries are determined to be international climate policy leaders and be very ambitious about the transformation of their energy sectors, replacing fossil fuel by renewable energy as quickly as possible which will be shown later in this article. Both Sweden and Denmark show no rush in this sector, though both have licenced domestic and foreign firms to explore promising fields. The attitude of both governments may be seen as relatively neutral and cautious at the moment. Responding to a growing public debate and the rise of a critical anti-fracking movement is rather contained as well.

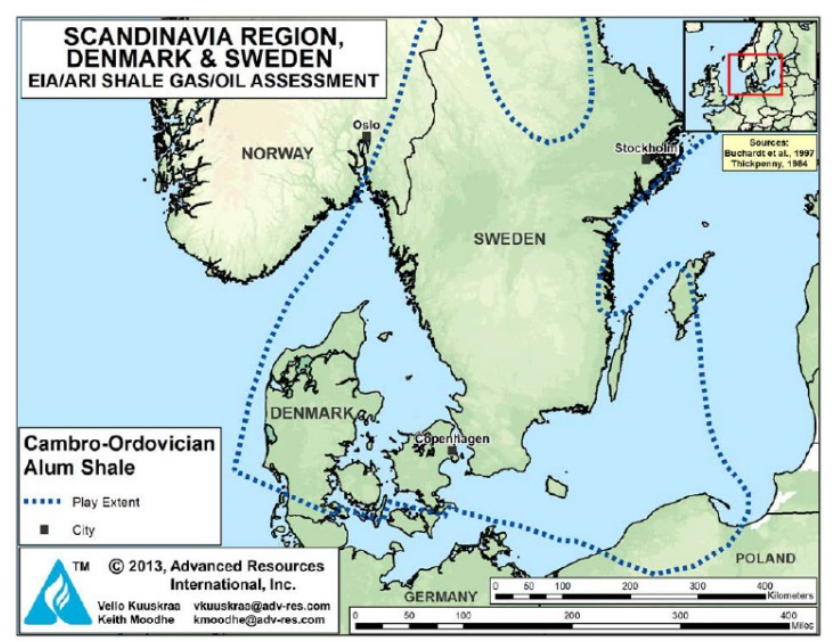

Figure 1: Area of technically recoverable shale oil and shale gas resources in Scandinavia (ARI - Advanced Resouces

International, 2013).

This article reviews political and public positions of Denmark and Sweden in relation to unconventional gas. Its aim is to show how shale gas development is dealt with. This examination includes the legal framework regarding exploration and exploitation of shale gas occurrences, as well as the projects of operating companies in this field. The public opinion dynamics and critical voices that have evolved from these issues are highlighted consequently. Some suggestions on future developments are offered in the final part of this article.

It is expected that the two countries will more or less consistently show a rather reluctant to dismissive position towards any further shale gas exploration and consequently also towards exploitation. Issues like being treated as a world leader in green attitude and energy development are not only in the mindset of policy makers in these countries, they already became part of the general character of Scandinavia. Thus, a new earth-exploiting format seems to be a challenge in many ways, as it is shown in the course of this article. The likelihood of changing over current energy strategies is evaluated in this article's conclusions.

\section{Denmark: \\ Shale Gas as Transition Fuel?}

The map of figure 2 gives an idea in which regions of Denmark potential shale gas extraction is plausible. "Sweet spots" are those areas which are characterised as organic-rich zones where gas extraction is possible given the geological features those areas show. "Non-sweet spots" do not provide good potential for future shale gas development (Durham University, 2012).
Notably, those sweet spots lying in a depth of below five kilometres are considerably harder to reach than those spots above this level. Light green areas therefore seem to be the most attractive for shale gas exploration and exploitation. The north of Denmark along with the island Seeland (Zealand), home to the capital Copenhagen, show the most onshore extraction opportunities for this type of unconventional gas development. Based on research by the U.S. Energy Information Administration (2013), a total of 4.5 trillion cubic metres is expected to lie in the Danish grounds, but only around $0.9 \mathrm{tcm}$ could be accessible by extracting it through fracking and therefore being technically recoverable. For Denmark itself, an area of around 17,400 million $\mathrm{m}^{2}$ is predicted for a depth of below $1,000 \mathrm{~m}$. The depths where shale gas is expected goes down to even 4,500 $\mathrm{m}$ in total (ARI, 2013).

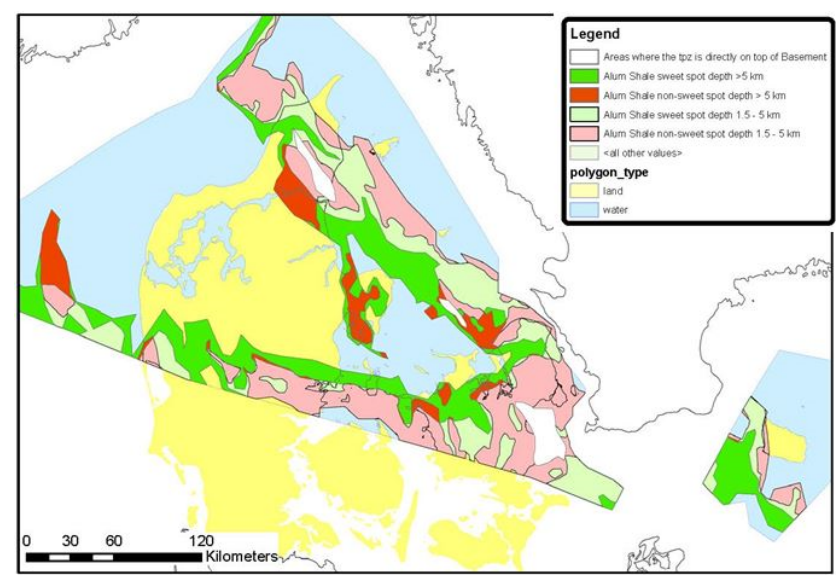

Figure 2: Danish shale gas in the Alum Shale, with "sweet spot" depths (NGU, NAG Directors Meeting, 2013).

Considering the fact that the development and extraction of shale gas seems to be a real possibility in Denmark, several groups of interests have grown rapidly, representing different concerns in regard to the topic. In general, it is possible to identify three main stakeholder groups that either have an interest in shale gas development or are affected by it in a certain way. Firstly, the government forms a stakeholder as it, for instance, gives the framework for the development of shale gas. Secondly, the industry has commercial interests and finally the general public, consisting of several smaller stakeholders wants to have a say in the related decisions as well.

\section{Government policy approach and legal framework}

Prime Minister Helle Thorning-Schmidt's current government is a coalition of Social Democrats, Social Liberals and the Socialist People's Party. It has parliamentary support by the RedGreen Alliance. Since winning the 2011 election, this government has taken a much stronger ecological position than its predecessor, Lars Løkke Rasmussen's right-leaning government coalition of the liberal-conservative Venstre and the Conservatives. The Ministry of Climate, Energy and Building is headed by Martin Ledegaard and is basically responsible for the administration of energy supply legislation, whereas application is handled by the Danish Energy Agency (Danish Ministry of Climate, Energy and Building, 2013). The agency is responsible for national and international production, supply and consumption of energy as well as efforts to reduce greenhouse gas emissions (Danish Energy Agency, 2013). Obviously, the environment ministry and its agencies also have a say in energy matters.

Denmark is very determined to design its energy policy around a stimulating approach for renewable energy sources. The government has established ambitious goals for 2050. For instance, 
by 2020 , more than 35 percent in final energy consumption should be supplied by renewable energy sources, 50 percent of electricity consumption by wind power; other aims include a reduction of gross energy consumption of 7.6 percent in comparison to 2010 and 34 percent reduction of greenhouse gas emission in relation to 1990 . Denmark's ultimate goal is to have 100 percent renewable energy in the energy and transport sectors by 2050. The agreement established to hold and support these targets includes 62 actions to enable Denmark to reach its aims. They cover areas such as energy efficiency, renewable energy for electricity production and usage in households and industries, policies regarding heating and research and development, including financing aspects (Danish Energy Agency, 2012).

Shale gas, in this context, tends to be seen as a bridging or transition energy source. "Shale gas can be a significant step toward a green transition", the DEA's International Director Hans Jørgen Koch has stated. "If we have access to more shale gas, it will help replace coal." (Total, 2013c). However, it would take much capital to produce shale gas, so profitability is in question. The actual point of making a profit with shale gas depends on too many factors and the initial investment that is made might take years to be reimbursed.

A key part of the economic equation is the decline of natural gas production in the North Sea. Denmark has been extracting offshore gas since the early $1980 \mathrm{~s}$, and this has made the country practically independent of gas imports. This could change quickly, and Denmark is expected to become a gas importer by the early 2020s unless alternatives can be found. This would have consequences for the country's finances, both in terms of additional cost for imports and a loss of revenue from domestic production.

Energy and climate minister Martin Lidegaard has explained:

[T] ransition away from fossil fuels will take time, which is why oil and gas will play a role for many more years. In the meantime tax revenue from the oil and gas production will benefit Danish society and our welfare. [...] Production of natural gas from the North Sea will continue, though all estimates show a general decline over the next 10-20 years. But new resources are still being found and developed in Denmark, and we're planning a new licensing round in the Danish part of the North Sea that is to be opened in 2013 (Natural Gas Europe, 2012)

Regulatory frameworks for the Danish oil and gas market are organised in two areas: licensing rounds and an "open door" procedure. Most Western parts of the North Sea, i.e. offshore fields, are subject to licensing rounds whereas the entire onshore region and remaining parts of offshore areas are structured by an “open door" procedure (Danish Energy Agency, 2013). Possible shale gas areas of Denmark fall into the "open door" category, by which companies can apply for licenses for a certain region expected to hold this type of unconventional gas. The procedure is based on a first-come, first-served policy. Up to June 2012 companies were able to apply for Danish areas with the purpose of developing shale gas. However, from this point of time on, the government suspended further "new licenses for exploration and production of hydrocarbons in onshore areas where the target is natural gas in shale layers". It reasoned that first, research for safe and environmentally friendly shale gas production should be fostered at first (Danish Energy Agency, 2013).

In 2010, Rasmussen's liberal-conservative government gave two licenses to a subsidiary of the French company Total, Total E\&P Denmark BV, which controls 80 percent of the licences, while Nordsøfonden (North Sea Fund), the Danish State's oil and gas company, owns a mandatory 20 percent share. Licences are for investigations and test drillings to evaluate potential shale gas occurrences on Danish grounds. Both parties committed to a work programme by accepting the license to explore the given areas within a certain time frame. In this specific case, only one exploration well per area is granted for research purposes. The aim of the exploration drillings is to find out whether the expected gas occurrences are sufficient and economically viable. As the Danish government participates in the tests by means of Nordsøfonden, it does not entirely give up control to the foreign French energy colossus (Van Waes, 2013).

\section{Exploration in Nordjylland and Nordsjaelland}

Total is the only company that currently holds licenses in Denmark for shale gas development purposes, at the Northern tip of mainland Denmark and on the Nordsjaelland island South of the Kattegat and West of the Danish Straits. Total has stated that there might be about five times as much shale gas onshore as the country has produced from the North Sea fields. Chances of finding commercially interesting quantities have been estimated to be about 20 percent. If exploration proves a success, production might start in 2020 (Total Group, 2013c). Total's license areas are mapped in figure 3 .

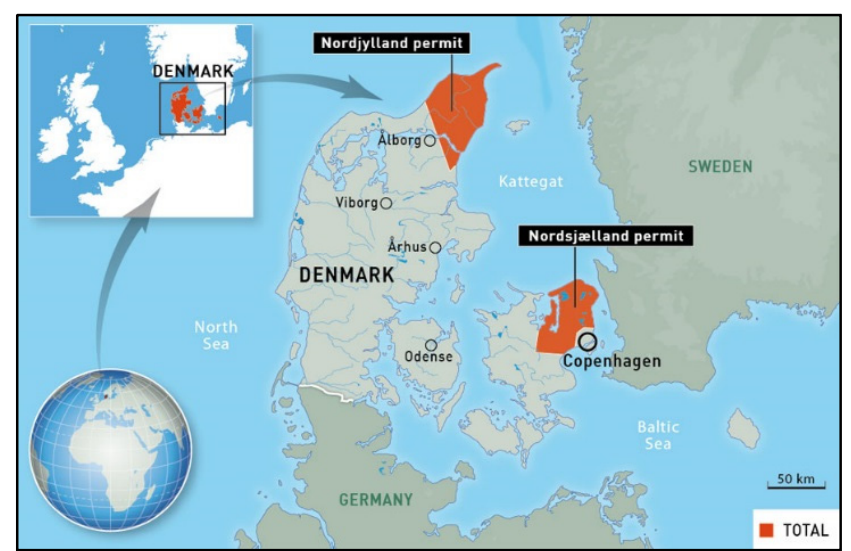

Figure 3: Danish licenses of Total Group (2013).

The energy giant was given six years for its research objectives, divided into three distinct phases where each phase has to show valid results for further appraisal processes. The first phase has already been completed and included preliminary studies from 2010 to 2012 where geological studies had to show the potential of shale gas occurrences in the selected areas. The research of this phase was conducted by means of existing data, source rock samples from outside the licensed areas, reprocessed data from seismic surveys, and drill cutting from past drilling in the areas of interest (Total Group, 2013).

The purpose of these tests was to find out how the rock would react to fracking. This can be estimated by the source rock thickness, organic contents of the rock and its mineral composition. The current, second phase comprises technical feasibility studies from 2012 to 2014. It is meant to confirm data by exploratory drilling and to give detailed information on the reservoir and its gas volumes.

In order to do so, first drilling in a vertical exploration well take place, as mentioned before, to take samples and conduct parameter measurements. Production tests are supposed to take place after the test drillings. Environmental and social impact studies, authorisation processes and the collection of additional seismic data are also included in this phase. Any further processes will then depend on the estimated quantity of gas, the fracking tests and further formerly unknown characteristics of the area. The last phase will start in 2014 and concerns the economic feasibility of fracking activities in the selected reservoirs. This includes evaluation of resources needed for the extraction, test drilling on horizontal levels, and a technical feasibility study. If all three phases show predicted positive results, Total will be 
able to apply for a production license, depending on own assessments and motivation to further proceed or not (Total Group, 2013).

The Nordjylland (Northern Jutland) project has concluded phase one. However, a lack of drilling rigs has delayed continuing with phase two as originally planned (Van Waes, 2013). In addition, delays in Nordjylland have been caused by demands for environmental impact reviews coming from the Frederikshavn municipality. This seems to have come about through local political pressure from environmental groups and activists. Indeed, the opposition group "Skifergas - Nej Tak" claims that this was a "first victory under our belts," encouraging the group to work toward a national ban on fracking (Skifergas Nej Tak, 2013). Meanwhile, construction of a drilling platform is supposed to be concluded by May 2014, making the rig operational (Holm, 2013).

The Nordsjaelland (Northern Zealand) project also reached phase two, and the rock formations are now subject to intensive research by the company. Nevertheless, Total has not yet drilled in this area either, as test and production drillings are only planned for phase three (Total Group, 2013).

\section{Public policy and public opinion}

In 2011, the issue of shale gas and its extraction was rarely discussed by the broad public in Denmark. The general media did not show great interest in the topic either; only the trade press followed foreign developments in regard to shale gas and fracking (PISM, 2011). As the new projects unfolded, however, criticism voiced that the only licence-holder, Total, made too little effort in public communications. Critics suggested that Total does not want the public to become aware and might be afraid of too much attention. According to one researcher, the company argued that the number of employees assigned to the project is simply too small to constantly keep the public informed. Furthermore, only test drillings take place at the moment which should not put the public into unrest as they are not considered as harmful (Van Waes, 2013).

Nevertheless, since December 2012, the firm has published a dedicated website, "Skifergas i Danmark" (skifergas.dk) in Danish and English with background information and news about its two projects. The site also explains the economic prospects for shale gas for Denmark and internationally. Since October 2013, a newsletter subscription is available. An exemplary screenshot of the website is shown in figure 4.

This effort should be understood in the context of political developments in the year 2012. In early 2012, energy minister Martin Ledegaard realised that no debate had risen in parliament or in the public. It should be noted that Denmark has a strong tradition in its political culture to build parliamentary and public consensus on long-term questions such as infrastructure and investment-intensive energy policy. After several meetings and technical briefings with the head of the Parliamentary Commission on Energy, the minister decided not to continue granting further licenses in regard to shale gas. However, Total could proceed with its current licenses.

The thrust of the minister's initiative aimed at clarifying the environmental conditions for responsible extraction before any new commitments could be made. Ledegaard stated:

If commercially interesting quantities of shale gas are found in Den mark, it will only be produced if it can be done in an environmentally sound way. The fact is that today we don't know whether we can produce natural gas from shale in the Danish subsoil. Exploration is at a very early stage [...] I'm well aware of possible issues in relation to protection of the environment in exploring for and producing shale gas. Before we approve a drilling programme for an exploration well, all issues in relation to protection of the environment and safety in general will be dealt with to safeguard such an operation. All precautions will be taken in order to protect any groundwater resources. (Natural Gas Europe, 2012)

For late 2013, the minister had plans to call for further meetings to evaluate the Danish results and experiences from abroad to discuss whether new licenses should be given out or not (Van Waes, 2013).

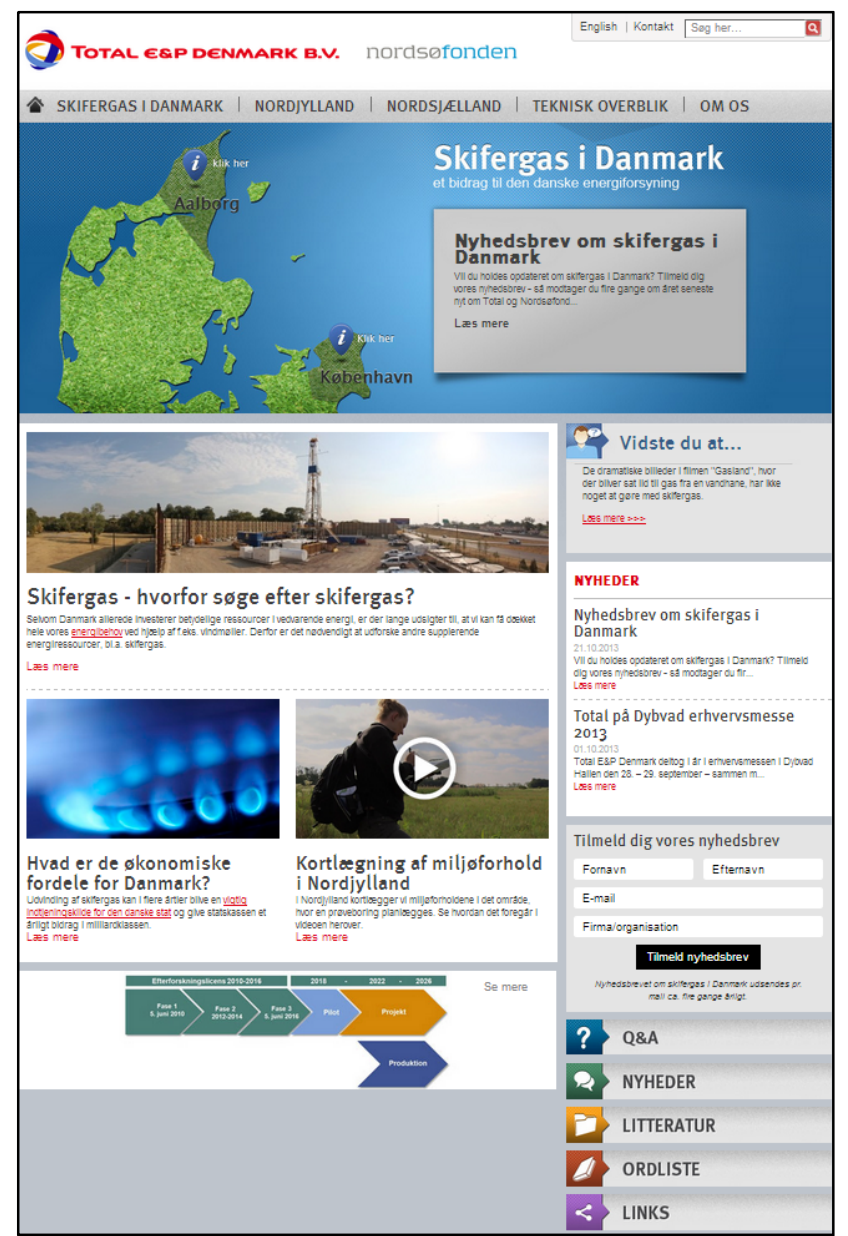

Figure 4: Total E\&P Denmark's public information website, "Skifergas i Danmark" at www.skifergas.dk. An English version is available at en.skifergas. $d k$

The topic still does not receive as much attention by the broad Danish public as some smaller stakeholders wish they would. Among these are a few non-governmental organisations, including Greenpeace Denmark, WWF Denmark, the Danish Society for Nature Conversation and "Skifergas - Nej Tak" (Van Waes, 2013). They mainly take an opposing position.

Concito, a green think-tank which analyses transition opportunities towards a climate-neutral Denmark without engaging in commercial or political interests, has published a report "Shale gas - good for the climate?" which received moderate attention and was intended to increase public debate. Concito emphasized the report did not come from a fundamental anti-fracking position but rather tried to promote a neutral and knowledge-based approach on dealing with shale gas; it clearly recognized that the U.S. has been able to strongly decrease carbon dioxide emission, replacing coal by natural gas. Shale gas was analysed as being more desirable than biomass because of environmental impacts.

Concito also pointed out that some public discussed issues have been based on misinformation; specifically, the film docu- 
mentary "Gasland" was criticized for poor and incorrect information and propagandistic motives. People should be open minded and rely on more trustworthy and non-biased sources (Concito, 2013).

However, Concito's managing director Thomas Færgeman downplayed certain pro-shale arguments in a later editorial and stated that in the context of Europe,

under current market conditions, shale gas will have no climate benefits. Only under certain political and market conditions that ensured that it replaced coal, would it be beneficial, but that would require either a significantly higher price for carbon quotas or coal, or lower gas prices. If none of these conditions are met, then shale gas would only result in a higher European consumption of fossil fuels and increased carbon emissions. (Færgeman, 2013)

Færgeman insisted that it is technically possible to keep extraction emissions to a minimum, "but it must be written into law or into extraction licences." Environmental impact assessments would be a must. In any case, shale gas would be unlikely to lead to greenhouse gas emissions reductions, "since any shale gas extracted in the EU would to a large degree only be replacing imported natural gas" (Færgeman, 2013). His critical conclusion was

the question of whether to extract shale gas then becomes a political decision based not on environmental considerations, but on foreign energy dependence and the potential financial gain from the sale of shale gas. At a time when scientists tell us that our fossil fuels must actually stay in the ground if we are to avoid catastrophic climate change, politicians would only be gambling with the planet's future if they went ahead and decided to increase the availability of fossil fuels on the world market. (Færgeman, 2013)

As public debate in Denmark slowly picks up speed on the question, it can be expected that such arguments, promoted by the influential environmental groups in the country, plus the growing protest movement, will be considered very seriously.

\section{Sweden: Mining Issues Beyond Shale}

The Alum Shale brings also Sweden on the map as a potential unconventional gas producer. Alum Shale gas is dry and in Sweden it is $1,000-2,100 \mathrm{~m}$ deep. Thus, recoverable Alum Shale gas reserves are estimated at about 0.3 trillion cubic metres. The Alum Shale in southern Sweden contains the black organic as well as the black and gray (dark brown) lithotypes. These lithotypes are important shale source rocks (ARI, 2013).

\section{Government policy and legal framework}

Sweden has an energy supply situation quite different from Denmark, which is reflected by government policy. It traditionally relies on nuclear power and hydropower for electricity generation, both of which make for very low $\mathrm{CO}_{2}$ emissions. Sweden has a very large potential for non-fossil fuel, renewable energy production such as biomass. The country has fairly low demand for natural gas and does not import much; it also has not much of a gas grid infrastructure. Sweden's energy supply has only a three percent natural gas share (Bosson, 2013).

Although Sweden is known for a relatively high energy consumption in Europe, energy engineering consultancy DNV notes that "the need for unconventional gas development is somehow limited in a country with this type of energy mix" (Stahl, 2011).

In relation to the EU Strategy 2020 and regarding significant protests against shale gas extraction, the Swedish government reviewed and evaluated its Mineral Strategy in 2011/12. The
Swedish Mineral Act is related to exploration permits and to mine concession minerals. Concession minerals are defined as certain mineral substances and industrial minerals - and therefore include oil and shale gas. The exploration permits give the holder the exclusive right to prospecting exploration. Thus, the holder has the obligation to create a work plan. The permit also gives the right to the landowners to submit comments on the work plan. Moreover, the act specifies that provisions about concession minerals are based on a common national interest in mining and the minerals industry. This means the mineral deposits have to be of an economically profitable quality, and the geographical location has to be suitable with the principles of natural resource management. The chief mining inspector of the Mining Inspectorate of Sweden holds the right to decide and may grant an exploitation concession (Government Offices of Sweden, 2012).

The Mining Inspectorate is the official body for the administration of mineral resources in Sweden and therefore carries out inspections as well. It belongs to the Ministry of Industry, Employment and Communications and works closely together with the Geological Survey of Sweden (SGU Personn, 2010).

Nevertheless, as the Scandinavian countries are known for their green attitude and as the use of chemicals is generally applicable for shale gas development, a prospected exploitation in Sweden has to be linked to the Environmental Code.

The overall purpose is a sustainable development and a healthy environment. Therefore, the act evaluates the obligation to set "precautionary measures that are necessary to prevent, hinder or combat damage or detriment to human health or the environment" (Government Offices of Sweden, 2012).

In terms of mining activities, this means the permit owner has to create a waste management plan and additionally a plan which carries out the activities for remediation. Furthermore, the remediation has to be trustworthy by means of financial security. This will be decided on by the responsible officials of the Swedish Ministry of Enterprise, Energy and Communications (Government Offices of Sweden, 2012).

An important role is taken by the public interest or a common national interest in Sweden, especially in regard to the environment and controversial projects, such as the ones involving hydraulic fracturing. Even if there are companies with exploration licences in Sweden, the government practically has given landowners the right of a veto.

A reason lies in the significant protests that have arisen among the Swedish people and a debate about the risks of unconventional gas extraction. But in general, the Minerals Act always links mining activities to the environment and the national interest. There is, for instance, a mandatory consultation by the operator during the initial stage of mining activities. The consultation includes the supervising authorities and the public, so that various stakeholders have the chance to make comments on the plan (Government Offices of Sweden, 2012).

\section{Exploration licences}

Four companies have received exploration licences in South and Central Sweden. Gripen Gas AB now has twelve authorisations for oil and gas exploration in Östergötland and Öland (Kalmar counties), an area which comprises around $583 \mathrm{~km}^{2}$ (Gripen Gas AB, 2012 and 2013). Energigas received four licences for exploration in Östergötland in Central Sweden. Another authorisation for an exploration project in Östergötland was given to Tekniska Verken Linköping $\mathrm{AB}$. Shell $\mathrm{AB}$ obtained three exploration licences for Skåne in South Sweden (Phillipe \& Partners, 2011).

Gripen Gas has claimed some successes in exploring for shale gas and has emphasized that developing the resource could allow Sweden to move away from oil and nuclear energy dependency 
(Gripen Gas AB, 2011). However, generally the news flow on Swedish industrial activity on unconventional gas exploration has been rather thin.

The first project to start, Shell AB, was the focus of much attention. The firm was initially very optimistic, saying its licence areas were promising and that there could be enough gas to cover Sweden's gas needs for at least ten years. The firm received licences in 2008/9 and began testing in 2010, immediately receiving public protests, lawsuits, and negative election-year statements from Social Democrat, Left and Green parties (Fouche, 2010). Upon disappointing results, Shell decided not to renew its exploration licenses in Sweden in 2011 (Gismatullin, 2011).

Gripen Gas received most of the exploration licences and is the principal gas explorer in Sweden. The firm's activities will be used to give a general idea on how shale gas development is managed in Sweden. According to Gripen Gas, exploration of shale gas includes three stages to test whether gas exists and of which quality it is present. Firstly, the company has to identify where gas exists. The second stage is the drilling of shallow wells to test the quality of the rock. If the first two steps are successful, the last stage is carrying out test of the gas flow volume. Gripen Gas identifies the most likely gas locations in their exploration areas with data from the Geological Survey of Sweden (SGU). The engineers analyse relevant data to get information about the possible gas deposits and its potential for producing. Moreover, they get first information about the quality of the gas to judge whether the shale quality is suitable for trapping. The next step is drilling to test the quality of the rock and in a best case discovery of Alum Shale deposits. If the drilling is successful, the volume of the shale gas deposit will be measured. Since the Minerals Act links mining activities to the national interest in economically viable projects, good gas flow rates are necessary for a commercial shale trapping. Therefore, Gripen Gas carries out different short tests and may drill other wells during the last phase.

Environmental aspects have to be taken into account. For this reason, Gripen Gas assures that hydraulic fracturing and the use of organic chemicals will be avoided. Instead, only water will be pumped down to cool the drilling bit while drilling and to encourage fractures in the Alum Shale. In certain cases with slant wells or near horizontal drilling, biodegradable mud may be used. Moreover, the company mentioned that it will not drill wells deeper than $150 \mathrm{~m}$ as "the Alunskiffer [Alum Shale] is shallow" (Gripen Gas, 2011). This stands in remarkable contrast to many other sources which see shale gas deposits in Sweden more around a depth of 1,000 to 2,100 metres (ARI, 2013).

Sweden's Environmental Code does not directly prohibit the use of chemicals while conducting mineral extraction activities. It may therefore be possible that Gripen Gas will, despite the assurances mentioned, select different methods and drill deeper in the future.

\section{Protests and public opinion}

Sweden has experienced significant protests against unconventional gas projects and insufficient regulation as well as insufficient local community decision-making power. This is not too surprising given the influential role of environmental organisations and a dedication to local democracy and participation in the country. Typical concerns about shale gas extraction and fracking are clearly present in Sweden, such as groundwater contamination through chemicals and seismic activity, but also problems of general land use regimes, noise and light pollution, heavy traffic and other effects of unpopular industrial projects in rural areas.
Shell AB, a subsidiary of the multinational Royal Dutch Shell Company, became a main target in the Southern region of Skåne, which by Swedish standards is a relatively densely populated area. Landowners and activist groups from diverse communities created a campaign platform, "Heaven or sHell," to inform the public about Shell's exploration plans, mobilise for protests, and circulate petitions (Heaven or sHell, 2013).

Protests even included some sabotage at Shell's project site, and the activists unsuccessfully tried court action against Shell, but the firm's projects were cleared by judges (Simpson, 2010). The company organized local community meetings to explain its projects together with scientists; some of these meetings have been described as "stormy" as some neighbours which had not been invited tried a public confrontation; in addition, the "Heaven or sHell" campaign, led by major landowner Count Carl Piper, hired public relations firm Henrik Westander to take the issues from local to national level (Koop, 2012, p. 6-10).

In 2010, the campaign used election year opportunities to stir political discussions, for example polling 300 candidates to state their opinion on shale gas and Shell's activities. It was quite successful in framing the issue in terms of what level of government should be enabled to make public decisions. Politicians showed considerable support for the idea that local, not central, bodies should have a say, even a right of veto (Sydsvenskan, 2010).

National environmentalist groups like Greenpeace Sweden, too, were and are active against shale gas development in Sweden. Such protests, which have included attempts to circulate petitions and involve the courts, created enough pressure to make the Swedish government review its energy minerals policy.

However, it is necessary to put the debate in perspective. Shale gas extraction is just one issue among others, some much bigger, in Sweden's mining debate. Sweden is a country with a traditionally strong mining industry, and in 1992, legislation was passed to increase minerals production, support the sector with more liberal regulation and less cost, and grow government revenue. The hope was and is for an economic boom which could benefit underdeveloped parts of Sweden. The dynamics over two decades have resulted in a "mining free-for-all," and recent new mining activities (e.g. iron and nickel) in Sweden's high north have created much controversy at different levels. State agencies have at times been seen as too industry-friendly, as the government even compared Sweden's mining resources to Norway's oil (Forssberg, 2013). Environmentalists have increased organized opposition. The political issues of whether and how citizens and local bodies can participate in project planning, and whether environmental protection is good enough, go far beyond any unconventional gas problems. Public attention has moved towards different mining policy questions. Large demonstrations against the "mining boom" and for strict regulations in the government's current review of Minerals Strategy took the streets in Stockholm and smaller cities in April 2013 (The Local, 2013).

Controversy on shale gas, by contrast, has cooled off since the 2010 election year activities. The early-2011 government changes in mineral law and Shell's 2011 exit have not been followed by any similar controversy.

Public debate has been limited by the fact that the country, unlike its neighbour Denmark, has few shale gas advocates in government or industry. Indeed, one public relations expert has described shale gas as a "non-issue" in Sweden, and few people whether economists or energy specialists or environmentalists know much about "fracking". She explains:

In Sweden, the largest Nordic energy consumer, shale gas is a nonissue. One reason for this is that voters and consumers do not have a relationship to natural gas. Nine in ten Swedish towns and cities are located outside the natural gas grid. Households and kitchen 
ranges that use gas can be found, but are viewed as something exotic. (Bosson, 2013)

Therefore, she claims that there is a lack of market interest in natural gas as a fuel. Policy ideas for investing in a national gas grid are relatively hopeless, as the combined heat and power market is claimed by waste fuels and bio fuels. She adds that for electricity production, "the doctrine on nuclear power is that it can only be replaced by renewable energy". Combined with opposition to mining, she posits that for shale gas deposits, "it would be nearly politically impossible to extract them" as the "Swedish conscience might not accommodate fracking" (Bosson, 2013).

\section{Conclusion}

The Danish and Swedish governments do see potential in shale gas extraction in the future as they allow test drillings in order to estimate the actual quantity of shale gas resources. The public has doubts about the opaque procedures to extract shale gas, as fundamental research seems to be insufficient. This lack of information causes concerns about how short and long-term effects have been considered by the operating parties so far.

Scandinavian countries' credibility as worldwide green leaders in energy production is also at stake. On the one hand, they are claiming to fast progress towards fossil fuel independence. On the other hand, Scandinavia considers opening up a new fossil fuel market to become more self-sufficient or to export surplus energy.

Even if shale gas extraction should become more environmentally friendly in terms of water usage and chemical supplements, the risk of occurring methane leakages is still not covered and adds up to a negative climate impact. All of these arguments simply are not in line with the conventional green attitude of the Nordic countries. It is entirely plausible that critical stakeholders demand an approach which clarifies the implications of the process. Especially when so many stakeholders are involved, the understanding of the topic before it is transformed into an everyday industrial activity is important.

Denmark's and Sweden's cases show similarities but also differences. Looking at Denmark, it is hard to forecast whether the state will allow fracking in the future. We expect that the country will put a priority on keeping its current position as a green innovator and make further investments in this area. Shale gas supply seems to have limited potential to convince a whole country to neglect its green energy policy approach, which finds strong support in the current government. Yet, Denmark has a growing economic mid- to long-term issue with its declining domestic gas production and a demand for gas. Arguments propose shale gas as a coal-replacing and imports-avoiding interim solution during transition to a fully renewable energy supply.

In Sweden, we expect a higher readiness among the current government to allow fracking, as a legal framework is in place. The Minerals Act says if all requirements (work plan, environmental code, and national interest) are fulfilled, exploration and production concessions are available. Community stakeholder rights, however, have become a red-hot issue in the larger mining debate. Politicians have been under a lot of pressure to grant local bodies a say on projects in the neighbourhood. Since this is essentially about the right to say no, or lay down restrictions and force negotiations, this may prove to be an obstacle for commercial projects. These, however, do not progress much technically or economically. Shell's exit is a case in point: the firm's decision to give up on shale gas in Sweden was probably more influenced by the disappointing test results than the public controversy its pioneering efforts generated. However, due to the Swedes' ecological attitude, underdeveloped gas demand, and the greener supply alternatives the country has, there is limited appeal for pushing risky technologies.

In Denmark and Sweden alike, communities and NGOs have organized themselves against the development of unconventional gas. They take part in, and push for, a general debate. It can be observed and forecasted that public acceptance is a critical factor. Information is key, but one very open question is whether and how concrete benefits to the communities could be offered. If so, this might help convincing citizens. These benefits can be in the form of financial benefits or funding for the municipality - as discussed intensely in Britain (Natural Gas Europe, 2013). One benefit that the publics in Denmark and Sweden generally expect, however, is that unconventional gas development should have positive, rather than negative, effects on the environment such as a reduction of $\mathrm{CO}_{2}$ emissions in the climate protection context. Scandinavia is likely, and well-advised, to be very careful weighing these arguments.

\section{References}

ARI - Advanced Resources International. (2013). Technically Recoverable Shale Oil and Shale Gas Resources: An Assessment of 137 Shale Formations in 41 Countries Outside the United States. Energy Information Administration, 138-144. Retrieved from http://www.eia.gov/ANALYSIS/STUDIES/WORLDSHALEGAS/pdf/ chaptersv

iii_xiii.pdf? zscb $=19162955$

Bosson, P. A. (2013, 2 September). Sweden: Shale What?. MSL Group blog, retrieved 3 December 2013 from http://blog.mslgroup.com/sweden-shale-what/

Concito. (2013). About CONCITO. Retrieved from http://concito.dk/node/214?language $=$ en

Control Risks' Offices. (2012). The global anti-fracking movement What it wants, how it operates and what's next. Shale Gas Whitepaper, 19-22. Retrieved from

http://www.controlrisks.com/Oversizedpercent20assets/shale_gas_whi tepaper.pdf

Danish Energy Agency. (2013). About the Danish Energy Agency. Retrieved from http://www.ens.dk/en/about-danish-energy-agency

Danish Energy Agency. (2012). Energy Policy in Denmark. Copenhagen, Denmark: Danish Energy Agency. (PDF Document). 8-9. Retrieved from http://www.ens.dk/sites/ens.dk

/files/politik/vedvarende-energisamarbejde-kina/bibliotek/danskpolitik-strategi/EnergyPolicyinDenmark-web.pdf

Danish Energy Agency. (2013). Oil and Gas Production in Denmark 2012 and Subsoil Use. Copenhagen, Denmark: Danish Energy Agency (PDF Document). 6-8. Retrieved from

http://www.ens.dk/sites/ens.dk/files/oil-gas/reports-oil-gasactivities/oliegas_rapport_uk___2012.pdf

Danish Ministry of Climate, Energy and Building. (2013). Ministerial Institutions. Retrieved from http://www.kebmin.dk/en/theministry/danish-ministry-of-climate-energy-and-building-ministerialinstitutions

Department of Mines and Energy. (2012). What is the difference between Conventional and Unconventional Gas? Northern Territory Government, Australia. Retrieved from

http://www.nt.gov.au/d/Minerals_Energy/index.cfm?header=Whatperc ent20ispercent20thepercent20differencepercent20betweenpercent20 Co nventionalpercent20andpercent20Unconventionalpercent20Gas?

Durham University. (2012). Unconventional Hydrocarbons - Shale Gas. Retrieved from

https://www.dur.ac.uk/unconventionals/topics/shale_gas/

Eberhardt, Feodoroff, Lui, Olivet, Trew (2013). The right to say no: $E U$ Canada trade agreement threatens fracking bans. Transnational Institute, Corporate Europe Observatory and the Council of Canadians, May 2013/ Issue Brief. Retrieved from http://corporateeurope.org/publications/right-say-no-eu-canada-tradeagreement-threatens-fracking-bans

Færgeman, T. (2013, 22 February). Danish shale gas without benefits for climate. Copenhagen Post, retrieved 3 Dec 2013 from 
http://cphpost.dk/news/opinion-danish-shale-gas-without-benefits-forclimate. $5110 . \mathrm{html}$

Forssberg, J. (2013, 14 Oct). Help yourselves, mining companies! Presseurop, retrieved 4 Dec 2013 from

http://www.presseurop.eu/en/content/article/4230921-help-yourselvesmining-companies [Original: Kom och ta vad ni vill ha. Fokus, retrieved 4 Dec 2013 fromhttp://www.fokus.se/2013/09/kom-och-ta-vadni-vill-ha)

Fouche, G. (2010, 21 May). Shell's shale gas hunt in Sweden under fire. Reuters, retrieved 4 Dec 2013 from

http://www.reuters.com/article/2010/05/21/us-shell-shalegas-swedenidUSTRE64K4LP20100521

Gismatullin, E. (2011, 28 July). Shell ends shale gas search in Sweden; invests in China fields. Bloomberg, retrieved 4 Dec 2013 from http://www.bloomberg.com/news/2011-07-28/shell-ends-shale-gassearch-in-sweden-invests-in-china-fields.html

Government Offices of Sweden. (2012). The Swedish Framework. Sweden's Mineral Strategy, 17-19. Retrieved from http://www.government.se/content $/ 1 / \mathrm{c} 6 / 21 / 89 / 86 / 30$ eccfae.pdf

Gripen Gas AB. (2012\&2013). 24 October 2012: Sandön Licence Award. 20 May 2013: Gripen Gas merges with Gotland Oil AB. Retrieved from http://www.gripengas.com/en/news

Gripen Gas AB. (2011). Exploration. Retrieved from http://www.gripengas.com/en/exploration

Gripen Gas AB. (2011). Environment. Retrieved from http://www.gripengas.com/en/environment

Heaven or sHell. (2013). Kommuner kräver vetorätt mot prospektering $i$ alunskiffer. Retrieved from http://heavenorshell.se/kommuner-kravervetoratt-mot-prospektering-i-alunskiffer

Heaven or sHell. (2013). Riskerna. Retrieved from $\mathrm{http} / /$ heavenorshell.se/riskerna

Holm, R. (2013, 14 November). Anlæg af nordjysk skifergasboreplads begynder til maj. Skifergas Nej Tak, retrieved 3 Dec 2013 from http://ing.dk/artikel/anlaeg-af-nordjysk-skifergasboreplads-begyndertil-maj-164276

Koop, W. (2012, 23 January). Frack EU: unconventional intrigue in Poland. B.C. Tap Water Alliance, Vancouver. Retrieved 4 Dec 2013 from http://www.bctwa.org/FrkPol-8-Chap6.pdf

Madsen, D., Have, J., Woodrow, J., Olsen, S. (2012). The shale gas debate in Denmark in 2012. Copenhagen, Denmark: IT-University of Copenhagen (PDF Document). Retrieved from http://sjersie.dk/wpcontent/uploads/2012/12/Shale-gas-Group-13.pdf

Ministry of Foreign Affairs of Denmark. (2013). Government and Politics. Retrieved from http://denmark.dk/en/society/government-andpolitics/

Natural Gas Europe. (2013, March 15th). Shell boss urges Europe to embrace shale. Natural Gas Europe Newsletter. Retrieved from http://www.naturalgaseurope.com/shell-urges-europe-embraceshale?utm_source=Natural+Gas+Europe+Newsletter\&utm campaign $=$ fd90e334b6RSS_EMAIL_CAMPAIGN\&utm_medium=email

Natural Gas Europe. (2013). UK Government unveils community benefits for shale gas exploration. Retrieved from http://www.naturalgaseurope.com/uk-community-benefits-shale-gas

Natural Gas Europe (2012, 25 January). Denmark hoping for shale gas Retrieved 3 Dec 2013 from

http://www.naturalgaseurope.com/denmark-hoping-for-shale-gas-4588

NaturalGas.org. (2011). Unconventional Natural Gas Resources. Retrieved from http://www.naturalgas.org/overview/unconvent ng resource.asp

Philippe \& Partners. (2011). Final Report on Unconventional Gas in Europe. European Commission, Energy DG, Library (DM28, 0/36), 11-14. Retrieved from http://ec.europa.eu/energy/studies/doc/2012_unconventional_gas_in_e urope.pdf

PISM - The Polish Institute Of International Affairs. (2011). Path to Prosperity or Road to Ruin? Shale Gas Under Political Scrutiny. Warsaw, Poland: Polski Instytut Spraw Miedzynarodowych (PDF Document). 44. Retrieved from http://www.pism.pl/files/?id_plik=8613

Seaton, Jim. (2013). Acceptance for shale development in Europe is growing. Natural Gas Europe. Retrieved from http://www.naturalgaseurope.com/shale-development-in-europe

SGU Personn, Åsa. (2010). What is Mining Inspectorate of Sweden? Retrieved from http://www.bergsstaten.se/index_e.htm
Shale Gas Information Platform. (2012). What are the benefits? Retrieved from http://www.shale-gas-information-platform.org/what-arethe-benefits.html

Shale Gas Information Platform. (2013). What are the risks? Retrieved from http://www.shale-gas-information-platform.org/what-are-therisks.html

Shale Gas Information Platform. (2013). The Basics - Operations. Retrieved from http://www.shale-gas-informationplatform.org/areas/basics-of-shale-gas/operations.html

Simpson, P. V. (2010, 19 April). Court clears Shell for Sweden gas drilling. The Local, retrieved 4 Dec 2013 from http://www.thelocal.se/20100419/26160

Skifergas Nej Tak (2013). Denmark in the international fight against fossil fuels and fracking. Retrieved 3 Dec 2013 from $\mathrm{http}: / /$ www.skifergasnejtak.dk/da/international/

Stahl, S. (2011, 4 May). No shale for Shell... In Sweden at least. DNV Anticipating the Future blog, retrieved 4 Dec 2013 from http://blogs.dnv.com/research/2011/05/no-shale-for-shell-in-swedenat-least/

Sydsvenskan (2010, 10 August). "Se till att regeringen stoppar Shell". Retrieved 4 Dec 2013 from http://www.sydsvenskan.se/opinion/aktuella-fragor/se-till-attregeringen-stoppar-shell/

The Local (2013, 21 April). Hundreds protest Sweden's mining boom. Retrieved 4 Dec 2013 from http://www.thelocal.se/20130421/47464

Total Group. (2013a). Natural Gas - The Danish Licenses: a step-by-step appraisal. Retrieved from http://www.total.com/en/ourenergies/natural-gas-/exploration-and-production/our-skills-andexpertise/unconventional-gas/total-a-world-class-player/francedanemark-202053.html

Total Group. (2013b). Nordsjaelland - What to expect. Retrieved from http://en.skifergas.dk/nordsjaelland/what-to-expect.aspx

Total Group (2013c, 21 June). What happens if the energy reserves in Europe are depleted? Retrieved 3 Dec 2013 from http://en.skifergas.dk/shale-gas-in-denmark/shale-gas-news/deaeuropean-energy-reserves-soon-depleted.aspx

Van Waes, A. (2013). Shale Gas Frames, Arguments and Coalitions in the Netherlands and Denmark - And the relation with renewable energy development. (Master Thesis). School of Innovation Sciences, Eindhoven University of Technology, Eindhoven. 78 - 89. Retrieved from http://alexandria.tue.nl/extra2/afstvers1/tm/Waes_2013.pdf 